\title{
УДК 378.14
}

\section{INNOVATIVE METHOD FOR PURCHASING PACKAGES ІНОВАЦЙНИЙ МЕТОД ВИКЛАДАННЯ ПРИКЛАДНИХ ПАКЕТІВ}

Golova O.A. / Голова O.O. c.t.s., as.prof. / к.m.н., доu. ORCID: 0000-0002-4903-4450

Vorobyov A.N. / Воробйов O.M. ORCID: 0000-0001-5314-1075

Lazarchyk-Vorobyova J.V. / Лазарчук-Воробйова Ю.В. ORCID: 0000-0002-7866-3299

National Technical University of Ukraine "Kyiv Polytechnic Institute named Igor Sikorsky", Kyiv, Victory Avenue, 37,03056

Національний технічний університет Украӥни «Київський політехнічний інститут імені Ігоря Сікорського», Київ, проспект Перемоги, 37,03056

Анотація. В статті розглядається новий метод оптимізащії проведення учбових занять при вивченні дисципліни «Інженерна та комп'ютерна графіка» із застосуванням прикладних пакетів за допомогою програми віддаленого адміністрування.

Ключові слова: сервер, сіть, «робочий стіл», сітьове викладання, віддалене адміністрування.

Вступ. При проведенні занять викладачі, як правило, застосовують традиційні інструменти, тобто дошка та крейда, але коли мова йде про заняття 3 комп'ютерних дисциплін, цього не достатньо, виникають певні труднощі 3 наданням матеріалу. Це пов’язано зі складністю будови сучасних прикладних пакетів і програм. Викладач не має змогу відобразити всі потрібні опції та підопції, вікна та підвікна, він потребує багато часу для відображення всіх багатоступеневих послідовних дій на дошці, що спричиняє погане засвоєння матеріалу. Але сучасні засоби надають можливість вирішити цю проблему нетрадиційно, застосовуючи для роботи «сітьове викладання».

Авторами було знайдено програми віддаленого адміністрування, які широко застосовуються сітьовими адміністраторами для забезпечення роботи в ciтi, але в учбовому процесі ці програми не мали свого застосування. Було обрано оптимальний варіант та розглянуто demo-версію програми на занятті 3 AutoCADy.

Автори мають на меті ознайомити читачів 3 новим методом викладання комп’ютерних дисциплін, як «сітьове викладання», розглянувши на прикладі роботу програми, оцінити іiі технічний рівень та принадність до учбового процесу.

Основна частина. Викладач здійснює адміністрування за допомогою сервера та сіті комп’ютерів, за якими працюють студенти (рис. 1).

При роботі в сіті у студентів на екрані традиційно 3'являється «робочий стіл» пакета AutoCAD [1]. Але в нашому випадку цей «робочий стіл» $\epsilon$ «робочим столом» сервера. Таким чином, викладач має змогу швидко і якісно показати студентові як працюють команди та опції. У студента на екрані відображаються всі дії та маніпуляції, здійснювані викладачем, що надає студентові можливість більш точно виконувати всі потрібні маніпуляції та 


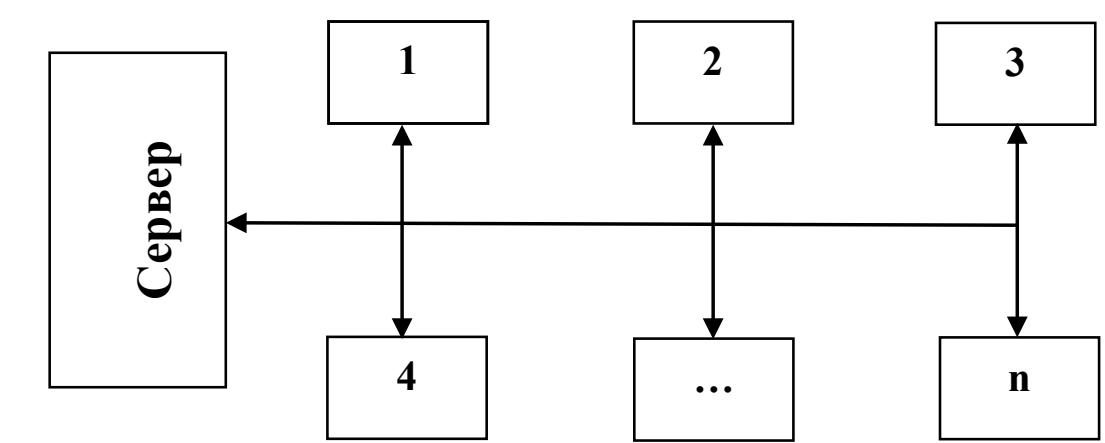

\section{Рис. 1. Схема розташування комп'ютерів при сітьовому} викладанні

завдання. В свою чергу, на викладацькому «робочому столі» відображаються всі «робочі столи» студентів і він може при хибних діях виправити помилки та недоліки в роботі студента (рис. 2).

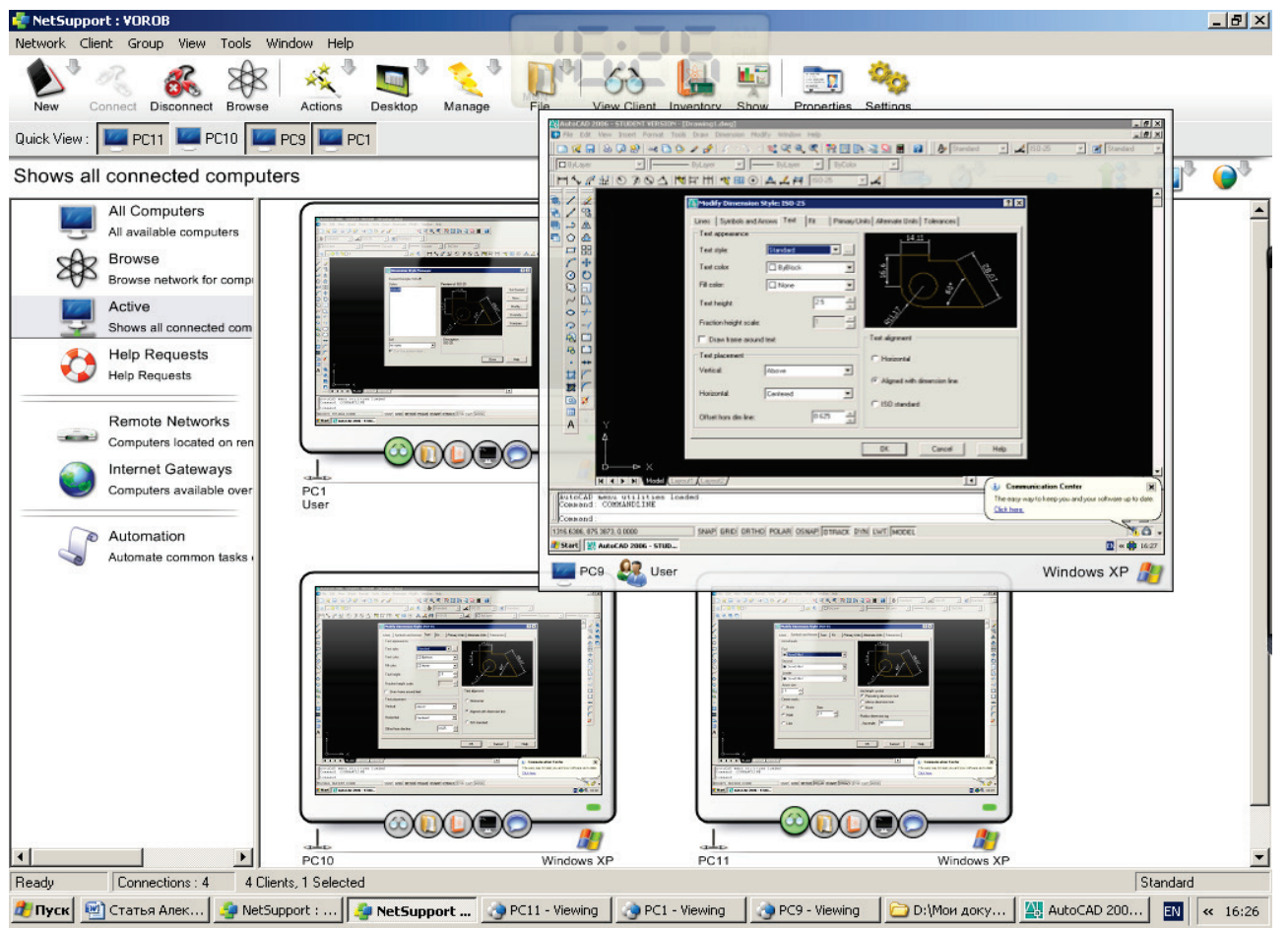

\section{Рис. 2. Робочий стіл викладача}

При недостатньому засвоєнні матеріалу студент має можливість повторити всі раніше проведені викладачем дії, що значно допомагає студентові в опануванні знаннями. В свою чергу, викладачеві така система надає змогу більш обгрунтовано оцінити працю студента, побачити всі його

дії, домашню підготовку тощо, що сприяє більш об'єктивному оцінюванню робіт студентів.

При подальшій роботі студента, якщо у нього виникли труднощі, викладач надає допомогу без вербального контакту, здійснюючи потрібні маніпуляції за своїм комп'ютером, відкривши його «робочий стіл» на своєму моніторі. Це надає можливість викладачеві швидко і тактовно виправити помилки у всіх 
студентів без винятку, що показово підвищує якість викладання та рівень знань студентів. Також викладачеві це дає зайвий час для надання студентам додаткового і цікавого матеріалу, відповідей на поставлені питання тощо.

та дає викладачеві час для надання студентам додаткового і цікавого матеріалу, відповісти на поставлені питання тощо.

Необхідність сітьового викладання доцільно розглянути на прикладі ознайомлення з діалоговим вікном «Modify Dimension Style» (рис. 3).

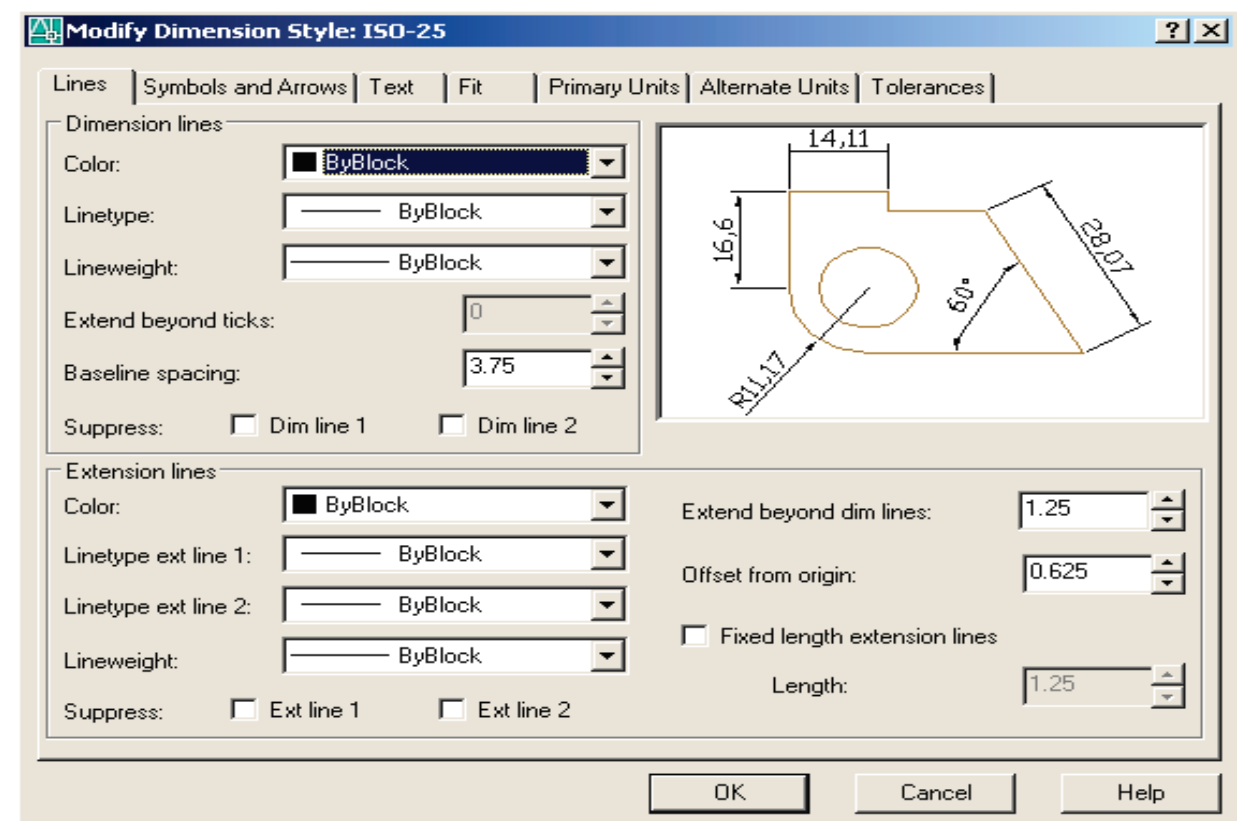

\section{Рис. 3. Діалогове вікно «Modify Dimension Style»}

Ця опція є дуже громіздкою і має в собі велику кількість вікон. При наданні матеріалу викладач не може відобразити всю структуру опції на дошці, розказати всі дії вкладок і пунктів. Для цього достатньо викладачеві відкрити це вікно на своєму комп'ютері і провести дії для формування розмірів. На моніторах студентів візуалізуються всі вікна даного діалогового вікна: Lines and Arrows, Text, Fit, Primary Units [2]. У кожному вікні викладач здійснює вибір пунктів та підпунктів, потрібних для створення розмірного стилю. При такому викладі, студенти скоріше засвоюють матеріал та формують розміри, що відповідають державним та галузевим стандартам.

Висновки. Проведений аналіз проблеми підтвердив необхідність цієї програми в учбовому процесі. Програма відповідає сучасному технічному рівню, допомагає в роботі викладачів та студентів, має широкі можливості для віртуального та дистанційного навчання, відкриває нові горизонти в навчанні прикладних пакетів та програм; значно полегшує викладання та засвоєння матеріалу. Сітьове викладання, як метод, буде дуже корисним, але автори ні в якій мірі не бажають зменшити значення традиційного методу, а лише збагатити та розширити його, зробити більш суттєвим при викладанні прикладних пакетів. 


\section{Лiтература:}

1. Ванін В.В., Перевертун В.В., Надкернична Т.О. Комп’ютерна інженерна графіка в середовищі AutoCAD: Навчальний посібник. - К.: Каравела, 2005. $336 \mathrm{c}$.

2. Ванін В.В., Бліок А.В., Гнітецька Г.О. Оформлення конструкторської документації. Навчальний посібник НМУВО, 2000. - 157c

Abstract. The article considers a new method of optimizing the conducting of training sessions in the study of the discipline "Engineering and Computer Graphics" with the application of application packages with the help of the remote administration program.

Keywords: server, network, desktop, networking, remote administration

\section{References:}

1. Vanin VV, Verevertun VV, Nadkernichna T.O. Computer engineering graphics in the AutoCAD environment: Tutorial. - K.: Karavela, 2005. - 336 pp.

2. Vanin VV, Blok AV, Gnitetskaya G.O. Design documentation. Textbook of the NMSO, 2000. $-157 \mathrm{pp}$.

Стаття відправлена: 03.04.2018 p.

(C) Голова O.O. 